\title{
Enhanced production of mouse $\alpha$-amylase by feeding combined nitrogen and carbon sources in fed-batch culture of recombinant Pichia pastoris
}

\author{
Du Bok Choi ${ }^{1}$ AND Enoch Y Park ${ }^{2, *}$ \\ ${ }^{1}$ Laboratory of Biotechnology, FCPV, B-K Company Ltd, 228 Soryong-dong, Gusan-si, \\ Jeonlabuk-do, 573-879, South Korea \\ ${ }^{2}$ Laboratory of Biotechnology, Department of Applied Biological Chemistry, Faculty of \\ Agriculture, Shizuoka University, 836 Ohya, Shizuoka 422-8529, Japan.
}

Received January 2005; Accepted 2005

\footnotetext{
* Corresponding author. Tel./Fax: +81-54-238-4887

E-mail address: yspark@agr.shizuoka.ac.jp (E.Y. Park)
} 


\begin{abstract}
The optimal culture conditions for attaining high levels of expression of mouse $\alpha$-amylase in the methylotrophic yeast Pichia pastoris were investigated. Cell growth and enzyme production were found to be optimal at a temperature of $28^{\circ} \mathrm{C}$ and a $\mathrm{pH}$ of 6.0 . Yeast extract and peptone were the most appropriate nitrogen sources for the expression of $\alpha$-amylase. When a mixture of $20 \mathrm{~g} / \mathrm{l}$ peptone and $20 \mathrm{~g} / \mathrm{l}$ yeast extract was used as the nitrogen source, $\alpha$ amylase activity reached $300 \mathrm{U} / \mathrm{ml}$. The expression of $\alpha$-amylase in a fed-batch culture using methanol as the sole carbon source reached $720 \mathrm{U} / \mathrm{ml}$ at 3 days of culture. However, when a methanol-to-glycerol mixture was used at ratio of 1:0.5 at a feed rate of $3 \mathrm{~g} / \mathrm{h}$, the maximum $\alpha$-amylase activity was $1.14 \mathrm{kU} / \mathrm{ml}$. Under the optimal culture conditions, when $40 \mathrm{~g} / \mathrm{l}$ of a mixture of yeast extract and peptone (1:1) was added to the culture at 3 and 5 days the final $\alpha$-amylase activity increased to $2.4 \mathrm{kU} / \mathrm{ml}$, which was 5.8- and 2.1-fold higher than the activity in the batch culture and in the fed-batch culture with feeding a mixture of methanol and glycerol at a ratio of 1:0.5, respectively. This study demonstrates that an addition of the appropriate amount of an organic nitrogen source to the fed-batch culture is effective to improve high level of expression of mouse $\alpha$-amylase in the methylotrophic yeast Pichia pastoris.
\end{abstract}

Keywords: Pichia pastoris; Mouse $\alpha$-amylase; Fed-batch culture; Alcohol oxidase 1 promoter; Foreign gene expression 


\section{Introduction}

The methylotrophic yeast Pichia pastoris has been proven to be an effective host for the production of recombinant proteins, because it as a host exhibits several advantageous expression systems involving certain eukaryotic posttranslational modifications [1]. $P$. pastoris is able to grow using on methanol as its carbon and energy sources, and it is known to attain very high cell density in a simple defined minimal salt medium [2]. These features render P. pastoris a good alternative host to achieve high levels of expression of heterologous proteins $[3,4]$.

Mouse $\alpha$-amylase isolated from the rat pancreas is a 55-kDa protein consisting of 496 amino acids in a single polypeptide chain [5] specifically carried out the hydrolysis of $\alpha$ 1,4 glucosidic linkages. In general, amylases possess the ability to hydrolyze the internal bonds of starch molecules on either side of $\alpha-1,6$ linkages. Because mouse $\alpha$-amylase plays a crucial role in the digestion of dietary starch, inhibition of its activity is of potential therapeutic value in the treatment of diseases such as diabetes and obesity. Indeed, the natural inhibitor Acarbose is effective at reducing postgrandial blood glucose levels and is now commercially available for the control of diabetes [6, 7]. Thus, both for clinical study and for commercial production, large amounts of mouse $\alpha$-amylase are currently needed.

We previously constructed a system for the production of mouse secretory $\alpha$-amylase in $P$. pastoris G2 containing multiple gene copies under the control of the alcohol oxidase 1 (AOX 1) promoter [8], and we obtained 290 units/ml of enzyme activity in a flask culture. However, in the present study, we aimed at achieving the high-level expression of heterologous protein in the methylotrophic yeast $P$. pastoris, and we determined the optimal supply of carbon and nitrogen sources, as well as the optimal culture conditions, in a fed-batch culture of 
recombinant $P$. pastoris G2. Applying these optimized culture conditions enabled us to markedly improve the production of mouse $\alpha$-amylase from the recombinant methylotrophic yeast $P$. pastoris.

\section{Materials and methods}

\subsection{Microorganism and culture media}

Recombinant Pichia pastoris G2 [8] was used throughout this experiment. Expression of the mouse $\alpha$-amylase gene in P. pastoris G2 is known to be under the control of the methanol-inducible alcohol oxidase 1 gene (AOX1) promoter. A single colony was selected from an agar slant on which the strain had been plated. This colony was cultivated in seed medium. The composition of the agar slant was as follows (g/l): agar, 10; glucose, 20; yeast extract (Oriental Kobo, Tokyo, Japan), 10; and Polypepton, 20. The seed medium contained the following ingredients (g/l): glycerol, 20; yeast nitrogen base w/o amino acid (Difco Laboratory Inc., Detroit, MI, USA, 7; yeast extract (Oriental Kobo), 10; and Polypepton, 20. For the induction of recombinant mouse $\alpha$-amylase using a 500-ml flask or jar fermentor, an induction medium was used. The composition of the induction medium was as follows (g/l): yeast nitrogen base w/o amino acid (Difco Laboratory Inc.), 3.5; yeast extract (Oriental Kobo), 5; Polypepton, 10; $\mathrm{K}_{2} \mathrm{HPO}_{4}$, 5; $\left(\mathrm{NH}_{4}\right)_{2} \mathrm{SO}_{4}, 0.1 ; \mathrm{MgSO}_{4}, 0.1 ; \mathrm{FeSO}_{4} \cdot 7 \mathrm{H}_{2} \mathrm{O}, 0.25$; $\mathrm{MnSO}_{4} \cdot \mathrm{H}_{2} \mathrm{O}, 0.2$; and biotin, $0.2 \mathrm{mg}$. Glycerol, methanol, or a mixture of both were used as the carbon source in the desired amount. Yeast extract, peptone, casamino acid, beef extract, and Polypepton were investigated as organic nitrogen sources; ammonium sulfate and urea were investigated as inorganic nitrogen sources. The $\mathrm{pH}$ level in these culture media was 
adjusted to 6.5 prior to steam sterilization. All media were sterilized at $121^{\circ} \mathrm{C}$ and $1.2 \mathrm{~atm}$ for $20 \mathrm{~min}$.

\subsection{Fed-batch culture with feeding carbon and nitrogen sources}

One loopful of P. pasteris slant culture was inoculated into a 500-ml Erlenmeyer flask containing $50 \mathrm{ml}$ of seed medium. The seed culture was carried out on a rotary shaker at 170 rpm at $30^{\circ} \mathrm{C}$. For the induction of expression of the $\alpha$-amylase gene, harvested cells grown for $18 \mathrm{~h}$ in $50 \mathrm{ml}$ of seed medium were resuspended in the induction medium, and then the cultures were grown at $28^{\circ} \mathrm{C}$ in a rotary shaker at $220 \mathrm{rpm}$. For the production of mouse $\alpha$ amylase, a 5-L jar fermentor (Model MDL 500, Marubishi Bioeng., Co., Tokyo, Japan) containing $2 \mathrm{~L}$ of induction medium was used. The rates of agitation and aeration were 500 rpm and $1.0 \mathrm{vvm}$, respectively. Oxygen-enriched air was supplied to maintain the dissolved oxygen (DO) concentration at levels higher than $10 \%$ saturation.

To determine the optimal ratio of methanol and glycerol as the carbon source, three different stock solutions were used, namely, 1:0.5; 1:1; and 1:2, which corresponded to concentrations of 221, 294, and $441 \mathrm{~g} / \mathrm{l}$, respectively. These stock solutions were introduced into the jar fermentors at a feed rate of $13.6 \mathrm{ml} / \mathrm{h}$, which corresponded to the carbon source flow rates of 3, 4, and $6 \mathrm{~g} / \mathrm{h}$. In cases involving the addition of a nitrogen source on culture days 3 and 5, a stock solution of $221 \mathrm{~g} / \mathrm{l}$ with a methanol-to-glycerol ratio of 1:0.5 was introduced into the jar fermentor at a feed rate of $27.3 \mathrm{ml} / \mathrm{h}(6 \mathrm{~g} / \mathrm{h})$. All experiments were carried out in triplicate and the averages were used to represent each group.

\subsection{Analytical methods}




\subsubsection{Concentrations of cell, methanol, and ammonia nitrogen}

The cell concentration was measured by measuring the optical density (OD) with a spectrophotometer as follows: a sample of culture broth was diluted approximately 100-fold, and the absorbance was measured at $600 \mathrm{~nm}$. The methanol concentration was measured by gas chromatography with a flame-ionized detector (Shimadzu GC-14B, Shimadzu, Kyoto, Japan). A glass column $(3 \mathrm{~m} \times 2 \mathrm{~m})$ was packed with PEG-20m 20\% Uniport OHP 60/80 (Shimadzu, Kyoto, Japan). The temperatures of the column, injection port, and detection chamber were 200,130 , and $130^{\circ} \mathrm{C}$, respectively. The gas pressures of nitrogen, hydrogen, and air were 140,65 , and $75 \mathrm{kPa}$, respectively. The ammonia nitrogen concentration was determined according to the Kdjeldhal method.

\subsection{2. $\alpha$-Amylase assay}

The culture broth was centrifuged at $3000 \mathrm{rpm}$ for $15 \mathrm{~min}$ at room temperature. The supernatant was used for the enzyme assay. Then, $0.25 \mathrm{ml}$ of enzyme sample diluted by the phosphate buffer solution was added to $0.25 \mathrm{ml}$ of $2 \%$ soluble starch, and the reaction mixture was incubated at $30^{\circ} \mathrm{C}$. At 5 min, the reaction mixture was withdrawn and was added to an equal volume of dinitrosalicylic acid reagent. The tubes were placed in a boiling water bath for $5 \mathrm{~min}$ and cooled to room temperature, at which point, $4 \mathrm{ml}$ of water was added to each tube. The amount of reducing sugar was then determined by measuring the absorbance at 540 nm using a spectrophotometer U-2001 (Hitachi Co. Ltd., Tokyo, Japan). One enzyme unit corresponded to the amount of enzyme that produced one micromole of glucose per min.

\section{Results}




\subsection{Effects of culture temperature on cell growth and $\alpha$-amylase activity}

In order to investigate the effects of temperature on cell growth and $\alpha$-amylase production, batch cultures maintained at various temperatures were carried out for $2 \mathrm{~d}$ using an induction medium containing $30 \mathrm{~g} / \mathrm{l}$ of methanol. The culture temperatures varied within the range of $24-34^{\circ} \mathrm{C}$ at intervals of $2^{\circ} \mathrm{C}$. The results are shown in Table 1 . The cell concentration cultured at 26 to $30^{\circ} \mathrm{C}$ was within a range of 58 to 60 , as determined at $\mathrm{OD}_{600}$, but in the case of samples cultured above $32^{\circ} \mathrm{C}$, the cell concentration decreased. Differences in methanol consumption were not observed, except for at $32^{\circ} \mathrm{C}$ and $34^{\circ} \mathrm{C}$. The $\alpha$-amylase activity generally increased with increases in culture temperature of up to $28^{\circ} \mathrm{C}$; $\alpha$-amylase activity reached $280 \mathrm{U} / \mathrm{ml}$, but decreased at temperatures exceeding $30^{\circ} \mathrm{C}$. This finding indicates that expression of the $\alpha$-amylase gene in the recombinant $P$. pasteris culture was significantly affected by the culture temperature.

\subsection{Effect of various nitrogen sources on cell growth and $\alpha$-amylase activity}

The selection of a nitrogen source is an important factor for obtaining successful $P$. pastoris cultures. In order to investigate the effects of various nitrogen sources on cell growth, residual methanol concentration, and $\alpha$-amylase activity, 5 different organic nitrogen sources and 2 different inorganic nitrogen sources were examined in batch cultures using an induction medium containing $30 \mathrm{~g} / \mathrm{l}$ methanol and a $40 \mathrm{~g} / \mathrm{l}$ nitrogen source. The results are shown in Table 2. When yeast extract, peptone, casamino acid, beef extract, and their mixtures were used, the cell concentrations were 66-70 as determined at $\mathrm{OD}_{600}$. However, when a nitrogen 
source containing either ammonium sulfate or urea was used, both the cell concentration and the expression of $\alpha$-amylase decreased remarkably; in addition, $\alpha$-amylase activity remained at only 130 and $140 \mathrm{U} / \mathrm{ml}$, respectively. On the other hand, when a mixture of $20 \mathrm{~g} / \mathrm{l}$ peptone and $20 \mathrm{~g} / \mathrm{l}$ yeast extract was used, the $\alpha$-amylase activity reached $300 \mathrm{U} / \mathrm{ml}$, which was approximately 2.2- to 2.3-fold higher that obtained with the inorganic nitrogen sources. Therefore, a mixture of $20 \mathrm{~g} / \mathrm{l}$ peptone and $20 \mathrm{~g} / \mathrm{l}$ yeast extract was used as the nitrogen source in all subsequent experiments.

\subsection{Effect of $p H$ on cell growth and $\alpha$-amylase activity}

In order to investigate the respective effects on cell growth and $\alpha$-amylase activity, the $\mathrm{pH}$ of the culture was controlled in a jar fermentor kept within a range of $\mathrm{pH} 3$ to 9 using ammonium hydroxide and hydrochloric acid solutions. The results are shown in Table 3. When the cultures were grown within a range of $\mathrm{pH} 5$ to 7, the cell concentration ranged from 68 to 72 at $\mathrm{OD}_{600}$. The concentration of methanol consumed ranged from 38.2 to $37.2 \mathrm{~g} / \mathrm{l}$. The maximum $\alpha$-amylase activity observed at pH 6.0 was $415 \mathrm{U} / \mathrm{ml}$. The optimum $\mathrm{pH}$ for the production of mouse $\alpha$-amylase by recombinant $P$. pastoris was 6.0.

3.4. $\alpha$-Amylase production in the batch culture of recombinant $\mathrm{P}$. pastoris with the addition of methanol

Figure 1 shows the cell concentration, as well as the concentration of residual methanol and the $\alpha$-amylase activity in the batch culture grown in a jar fermentor. To avoid methanol depletion, $20 \mathrm{~g} / \mathrm{l}$ of methanol was added to the culture at 1 and $4 \mathrm{~d}$, respectively. The 
dissolved oxygen concentration decreased drastically due to cell growth until $12 \mathrm{~h}$ of culture; however, the dissolved oxygen concentration increased and was maintained at 70-80\% saturation thereafter (Fig. 1a). The methanol concentration decreased steadily until day 4 of the culture period, after which the rate of methanol consumption began to slow down, finally remaining at $23 \mathrm{~g} / \mathrm{l}$ (Fig. 1b). The cell concentration increased until day 3 of culture, but then began to decrease after $4 \mathrm{~d}$ of culture, and remained at 75 as observed at $\mathrm{OD}_{600}$ (Fig. 1c). The $\alpha$-amylase activity increased with increases in the culture period of up to $3 \mathrm{~d}$, and reached $720 \mathrm{U} / \mathrm{ml}$ when the cell concentration reached 95 as observed at $\mathrm{OD}_{600}$ (Fig. 1d). No degradation of $\alpha$-amylase was observed during $6 \mathrm{~d}$ of culture.

3.5. $\alpha$-Amylase production in the batch culture of recombinant $\mathrm{P}$. pastoris grown on a mixed carbon source

Since glycerol is a good carbon source for the growth of P. pastoris, glycerol was mixed with methanol and was applied to the cultures. Carbon sources with a methanol-to-glycerol ratio of $1: 0.5,1: 1$, or $1: 2$, were fed to each of the respective cultures at a feed rate of 13.6 $\mathrm{ml} / \mathrm{h}$. When the carbon sources were applied at feed rates of 3,4 , and $6 \mathrm{~g} / \mathrm{h}$, it was observed that 31, 16, and $2 \mathrm{~g} / \mathrm{l}$ methanol, respectively, remained in the culture media (Fig. 2a). These results corresponded to the observed consumed methanol concentrations of 115, 130, and 145g/l. The cell concentration increased with increases in the glycerol ratio (Fig. 2b) and did not decrease additionally, regardless of the glycerol supply. When a carbon source with a ratio of 1:0.5 was used, the maximum $\alpha$-amylase activity, $1.14 \mathrm{kU} / \mathrm{ml}$, was obtained at day 6 culture (Fig. 2c). In the case of a mixture ratio of 1:2, the yield of $\alpha$-amylase was lower than 
that when the mixture ratio was 1:0.5. In the case of a surplus of glycerol, ethanol was detected as a byproduct (data not shown).

3.6. $\alpha$-Amylase production in fed-batch culture of recombinant P. pastoris fed on carbon and nitrogen sources

Fed-batch cultures were grown on a carbon source to obtain high levels of expression of $\alpha$-amylase. Here, $221 \mathrm{~g} / \mathrm{l}$ of a carbon source at a mixture ratio of 1:0.5 was applied to the cultures at a feed rate of $27.3 \mathrm{~m} / \mathrm{h}(6 \mathrm{~g} / \mathrm{h})$. In order to prevent starvation due to depletion of the nitrogen source, a mixture of $20 \mathrm{~g} / \mathrm{l}$ yeast extract and $20 \mathrm{~g} / \mathrm{l}$ peptone was added at 3 and 5 days of culture. As regards the conventional culture lacking the addition of a nitrogen source, the ammonia nitrogen was found to be completely consumed at 3 days of culture (Fig. 3a). The methanol accumulated without consumption, and increased with increases in the duration of the culture period, finally reaching $50 \mathrm{~g} / \mathrm{l}$ (Fig. 3b). However, as regards the cell concentration, increases were observed to correspond with increases in the duration of culture (Fig. 3c). Mouse $\alpha$-amylase activity was also found to increase with increases in the duration of the culture period of up to 3 days; however, after 6 days of culture, no additional increases were observed (Fig. 3d).

On the other hand, when a mixed nitrogen source was added to the culture during $\alpha$ amylase expression, the methanol concentration was maintained at levels lower than $10 \mathrm{~g} / \mathrm{l}$, and the total consumed methanol concentration was $285.4 \mathrm{~g} / \mathrm{l}$. This value was approximately 1.2-fold higher than that observed in the conventional culture. Despite the similarity between the concentration of this cell culture and in that of the conventional culture, the maximum $\alpha$ - 
amylase activity reached $2.4 \mathrm{kU} / \mathrm{ml}$, which was about 1.7 -fold higher than that of the conventional culture (Fig. 3d).

\section{Discussion}

The yeast $S$. cerevisiae has been used extensively as a host for the expression of foreign genes in a number of cases, in particular those requiring fermentation; a comprehensive body of knowledge is available on the genomic and biological background of yeast. However, the yields of the secreted protein products are low, and there remain hindrances to the secretion of certain proteins [2]. Many of the proteins secreted by S. cerevisiae are not found free in the medium, but rather exist in the periplasmic space. Although S. cerevisiae has been used as a host for the expression of recombinant proteins, the methylotrophic yeast $P$. pastoris has become an alternative host for the production of several valuable proteins, due to its ability to express high levels of heterologous proteins, together with the ability of this yeast to grow to very high cell densities. In this latter host system, the expression of the heterologous gene is under the control of a stringently regulated $A O X 1$ promoter. This expression system has the potential for high levels of expression and secretion of the recombinant product [9]. The levels of expression of heterologous proteins in P. pastoris depends on various factors such as the signal peptide used, the number of copies of the gene integrated into the chromosome, and the culture conditions used for growth and induction [3].

In this study, in order to achieve the high yields $\alpha$-amylase using recombinant $P$. pastoris G2 with a fermentation process, various environmental factors such as temperature, $\mathrm{pH}$, and carbon and nitrogen sources were investigated. The optimal culture temperature for $\alpha$ amylase production using recombinant $P$. pastoris $\mathrm{G} 2$ was $28^{\circ} \mathrm{C}$. 
$\mathrm{pH}$ is an important factor in maintaining the stability of recombinant proteins secreted by P. pastoris. Control of the $\mathrm{pH}$ is effective at minimizing the proteolytic degradation of foreign proteins expressed by $P$. pastoris [10, 11]. Xavier et al. [12] also reported that the $\mathrm{pH}$ of the culture medium had an important effect on the expression of influenza A virus hemagglitinin; in this case in particular, the highest yield was obtained at pH 8.0. Rosenfeld et al [13] observed that the recombinant form of hirudin, a potent thrombin inhibitor produced during culture at $\mathrm{pH}$ 5.0, was subject to extensive proteolysis. However, maintenance of the culture at pH 3.0 during glycerol feeding and methanol induction dramatically stabilized final recombinant form of hirudin by minimizing proteolysis. In our study, when the cultures were controlled at $\mathrm{pH}$ 6, the mouse $\alpha$-amylase activity expressed in P. pastoris remained stable, and high levels of $\alpha$-amylase expression were observed.

Generally, a three-stage process is utilized for the production of foreign proteins in a fermentor using $P$. pastoris. At the first stage, the cells are cultured in a glycerol-containing medium, which is used as the carbon source to accumulate biomass. The second stage is the fed-batch transition phase in which glycerol is fed to the culture at a growth-limiting rate in order to further increase the biomass and to prepare the cells for induction. At the third stage, the induction phase is initiated by the addition of methanol at a slow rate. An alternative, the mixed feed-induction of methanol and glycerol, improves cell viability and allows for a shorter induction phase, and yields a higher rate of protein production. However, excess glycerol is a strong repressor of the $A O X 1$ promoter, and can result in lower yields than cultures supplied with methanol alone. Brierley et al. [14] expressed the bovine lysozyme from the $A O X 1$ promoter with feed containing different glycerol-to-methanol ratios, and they observed a more rapid growth rate and a faster methanol uptake rate than were observed in 
cultures lacking such supplementation. Recombinant protein production in these experiments was reported to be a function of both the glycerol feed rate as well as the methanol feed rate. Fed-batch cultures supplied glycerol at an appropriate feed rate can maintain cell growth at a constant rate due to the maintenance of low concentrations of the substrate. Dunn and Mor [15] have shown that fed-batch cultures supplied with energy sources at low feed rates can attain balanced growth and a quasi-steady state of production; their approach provided the same information as would a chemostat without the necessity of shifting between steady states. Loewn et al [16] also investigated the mixed-feed ratios of glycerol and methanol for the effective production of sea raven type II antifreeze protein. They also described a mixed feeding strategy in which feeding was initiated at a 2:1 ratio, and gradually the proportion of methanol in the feed was increased until methanol began to accumulate. The maximum methanol uptake rate was achieved when a mixed-feed ratio between 1:1 and 1:3 was observed. This method of slowly increasing the proportion of methanol during the administration of the methanol-glycerol mix resulted in the highest recombinant protein expression levels and shortened the induction phase from $175 \mathrm{~h}$ to $45 \mathrm{~h}$. However, the supplementation of mixed feed at high rates can also result in the production of inhibitory levels of methanol. Similar results were obtained with a strain of $P$. pastoris producing mouse $\alpha$-amylase. In particular, when a mixture ratio of $1: 2$ of methanol to glycerol was applied, the yield of $\alpha$-amylase was lower than that produced with a mixture ratio of 1:0.5. The ethanol concentration observed in that case was increased with increases in the glycerol concentration applied (data not shown). When methanol and glycerol were supplied to the cultures at a ratio of $1: 0.5$, the maximum specific $\alpha$-amylase activity was $7.50 \mathrm{kU} / \mathrm{l} / \mathrm{OD}_{600}$, which was similar to that of the fed-batch culture using methanol only; however, the rate of $\alpha$-amylase production 
was $7.92 \mathrm{kU} / \mathrm{l} / \mathrm{h}$, which was approximately 1.6 -fold higher than that of the batch culture supplied only with methanol. The $\alpha$-amylase activity was thus approximately1.6-fold higher than that of the fed-batch culture using methanol only.

As regards the production of heterologous proteins, a number of authors have reported that the type and concentration of the nitrogen source exert some influence on the product yield. For example, Chauhan et al. [17] found that supplementation with casamino acid or alanine in a culture of $P$. pastoris resulted in a 2-fold increase in the level of expression of hepatitis B virus surface antigen compared to that observed without this supplement in $P$. pastoris. With the addition of $10 \%$ peptone or $0.2 \mathrm{~mol} / \mathrm{l}$ of arginine to the culture medium, the fibrinolytic activity of prourokinase-annnexin $\mathrm{V}$ reached $7.8 \mathrm{kU} / \mathrm{ml}$ at $168 \mathrm{~h}$ of culture, which was more than 10-fold that obtained without the supplement in P. pastoris [18]. In addition, Polypepton was used as the feed medium for effective $\beta$-galactosidase production in a perfusion culture from P. pastoris using a shaker ceramic membrane flask and a two-stage fed-batch culture [19]. Ammonia sulfate was also used for preventing the sereprotease degradation of recombinant human serum albumin secreted by P. pastoris during culture [20]. However, when a mixture of ammonium sulfate or urea was used in the culture of P. pastoris G2, cell growth and the expression of $\alpha$-amylase were repressed. In our case, yeast extract and peptone were the most appropriate nitrogen sources; in particular, when the mixture of yeast and peptone was used, the mouse $\alpha$-amylase activity was $300 \mathrm{U} / \mathrm{ml}$, i.e., approximately 2.3-fold higher than that obtained with a mixture of involving either ammonia sulfate or urea. As for the inorganic nitrogen source, since it is easily ionized the $\mathrm{pH}$ change is shown in the medium. Amino acid content of the inorganic nitrogen source is quite lower than that of the organic nitrogen source. Actually P. pastoris cells require glutamic acid, alanine, valine, 
leucine, and tyrosine in the nitrogen source, which was found by our amino acid analysis (data not shown). We think that $\mathrm{pH}$ variation and low content of amino acids of the inorganic nitrogen source gave lower cell growth and $\alpha$-amylase activity.

In this study, we found that the addition of a mixture of yeast extract and peptone was effective for achieving high levels of expression of mouse $\alpha$-amylase. The enzyme production rate of mouse $\alpha$-amylase was $14.3 \mathrm{kU} / \mathrm{l} / \mathrm{h}$, which was approximately 1.6 -fold higher than that achieved in the absence of the nitrogen sources. As regards the product yield (enzyme activity/g consumed methanol and glycerol), an increase of approximately 1.3-fold was observed in comparison to the yield obtained without a nitrogen source. This finding indicates that the combination of an optimal mixture ratio of methanol to glycerol, together with the addition of yeast extract and peptone, was highly effective for obtained high levels of expression of mouse $\alpha$-amylase.

Table 4 summarizes the $\alpha$-amylase production yields in $P$. pastoris cultures. When the fed-batch culture was supplied a carbon source with a mixture ratio of 1:0.5, the maximum cell concentration was 152 at $\mathrm{OD}_{600}$, which was 1.6-fold higher than the maximum cell concentration of the batch culture to which only methanol was added. The $\alpha$-amylase activity was $1.14 \mathrm{kU} / \mathrm{ml}$, which was ca. 1.6-fold higher than that observed in the batch culture to which only methanol was added.

Previously, we reported this level of mouse $\alpha$-amylase production in a fed-batch culture of recombinant $S$. cerevisiae 20B-12 [21]. The production rates of $\alpha$-amylase under the control of the phosphoglycerate kinase (PGK) gene promoter and Saccharomyces cerevisiae invertase (SUC2) gene promoter were 3.0 and $4.3 \mathrm{kU} / \mathrm{l} / \mathrm{h}$, respectively. Our result, $14.3 \mathrm{kU} / \mathrm{l} / \mathrm{h}$, was 3.3- to 4.8-fold higher that in the culture of recombinant $S$. cerevisiae 20B-12. This result 
demonstrates that as a host, $P$. pastoris has significant potential for the production of foreign gene products.

\section{References}

[1] Buckholz RG, Gleeson MAG. Yeast systems for the commercial production of heterologous proteins. Bio/Tech 1991; 9: 1067-1072.

[2] Romanos MA, Scorer CA, Clare JJ. Foreign gene expression in yeast: a review. Yeast 1992; 8: 423-488.

[3] Gregg JM, Tschopp JF, Stillman G, Siegel R, Akong M, Craig WS, Buckholz RG, Madden KR, Kellaris PA, Davis GR, Smiley BL, Cruze J, Torregrossa R, Velicelebi G, Thill GP. High-level expression and efficient assembly of hepatitis B surface antigen in the methylotrophic yeast, Pichia pastoris. Bio/Tech 1987; 5: 479-485.

[4] Tschopp JF, Sverlow G, Kosson R, Graige W, Grinna L. High-level secretion of glycosylated invertase in the methylotrophic yeast, Pichia pastoris. Bio/Tech 1987; 5: 1305-1308.

[5] Ott H, Raymonde B, Young RA. Tissue-specific expression of mouse $\alpha$-amylase gene. Cell 1980; 21: 179-187.

[6] Ledermann H, Hoxter G. Effect of Acarbose on postgrandial increase in blood glucose. Fortschritte der medizin 1994; 112: 467-470.

[7] Noda K, Umeda F, Nawata H. Effect of Acarbose on glucose intolerance in patients with non-insulin-dependent diabetes mellitus. Diabet Res Cli Frac 1997; 37: 129-136.

[8] Uehara H, Choi DB, Park YS, Okabe M. Expression of $\alpha$-amylase gene in methylotrophic yeast Pichia pastoris. Biotechnol Bioprocess Eng 2000; 5: 7-12. 
[9] Cregg JM, Vedvik TS, Raschke WC. Recent advances in the expression of the foreign genes in Pichia pastoris. Bio/Tech 1993; 11: 905-910.

[10] Werten MW, Vanden Bosch TJ, Wind RD, Mooibroek H, De Wolf FA. High-yield secretion of recombinant gelatins by Pichia pastoris. Yeast 1999; 15: 1087-1096.

[11] Scorer CA, Buckholz RG., Clare JJ, Romanos MA. The intracellular production and secretion of HIV-1 envelope protein in the methylotrophic yeast Pichia pastors. Gene 1993; 136: 111-119.

[12] Xavier S, Peter V, Wim M, Maras SN, Sabine N, Roland C, Walter F, Willy MJ. Protection of mice against a lethal influenza virus challenge after immunization with yeast-derived secreted influenza virus hemagglitinin. Eur J Biochem 1999; 260: 166175.

[13] Rosenfeld SA, Nadeau D, Tirado J, Hollis GF, Knabb RM, Jia S. Production and purification of recombinant Hirudin expressed in the methylotrophic yeast Pichia pastoris. Protein Exp Purif 1996; 8: 476-482.

[14] Brierley RA, Bussineau C, Kosson R, Melton A, Siegel RS. Development of recombinant Pichia pastoris expressing the heterologous gene bovine lysozyme. Biochem Eng VI Ann NY Acad Sci 1990; 589: 350-363.

[15] Dunn IJ, Mor JR. Variable-volume continuous cultivation. Biotechnol Bioeng 1975; 17: 1805-1822.

[16] Loewn M, Liu X, Davies PL, Daugulis AJ. Biosynthetic production of type II fish antifreeze protein. Appl Microbiol Biotechnol 1997; 48: 480-486.

[17] Chauhan AK, Aroa D, Khanna N. A novel feeding strategy for enhanced protein production by fed-batch fermentation in recombinant Pichia pastoris. Process Biochem 
1999; 34: 139-145.

[18] Ohya T, Morita M, Miura M, Kuwae S, Kobayashi K. High-level production of prourokinase-annexin V chimerase in the methylotrophic yeast Pichia pastoris. J Biosci Bioeng 2002; 94(5): 467-473.

[19] Ohashi R, Mochizuki E, Kamoshita Y, Suzuki T. High-level expression of methanolinducible $\beta$-Galactosidase gene by perfusion culture of recombinant Pichia pastoris using a shaken ceramic membrane flask. J Ferment Bioeng 1998; 86: 44-48.

[20] Ohda T, Ohyama M, Ohi H, Tomomitsu K, Omura T. High-level expression of recombinant human serum albumin from the methylotrophic yeast Pichia pastoris with minimal protease production and activation. J Biosc Bioeng 2000; 89: 55-61.

[21] Park YS, Shiba S, Iijima S, Kobayashi T. Comparison of three different promoter systems for secretary $\alpha$-amylase production in Fed-batch cultures of recombinant Saccharomyces cerevisiae. Biotechnol Bioeng 1993; 41: 854-861. 
Table 1

Effect of culture temperature on cell growth, methanol consumption, and $\alpha$-amylase activity

\begin{tabular}{cccc}
\hline Temperature $\left({ }^{\circ} \mathrm{C}\right)$ & $\begin{array}{c}\text { Cell concentration } \\
\left(\mathrm{OD}_{600}\right)\end{array}$ & $\begin{array}{c}\text { Residual methanol } \\
\text { Concentration }(\mathrm{g} / \mathrm{l})\end{array}$ & $\begin{array}{c}\alpha \text {-Amylase activity } \\
(\mathrm{U} / \mathrm{ml})\end{array}$ \\
\hline 24 & $59.0 \pm 0.4$ & $6.9 \pm 0.1$ & $255.0 \pm 1.3$ \\
26 & $60.0 \pm 1.6$ & $5.2 \pm 0.1$ & $260.0 \pm 1.7$ \\
28 & $61.0 \pm 1.3$ & $2.8 \pm 0.1$ & $280.0 \pm 1.1$ \\
30 & $58.0 \pm 0.9$ & $5.0 \pm 0.2$ & $260.0 \pm 0.4$ \\
32 & $40.0 \pm 0.1$ & $17.5 \pm 0.1$ & $150.0 \pm 1.5$ \\
34 & $35.0 \pm 1.1$ & $25.1 \pm 0.1$ & $50.0 \pm 2.1$ \\
\hline
\end{tabular}


Table 2

Effect of nitrogen source on cell growth and $\alpha$-amylase expression

\begin{tabular}{lccc}
\hline \multicolumn{1}{c}{ Nitrogen sources } & $\begin{array}{c}\text { Cell concentration } \\
\left(\mathrm{OD}_{600}\right)\end{array}$ & $\begin{array}{c}\text { Residual methanol } \\
\text { concentration }(\mathrm{g} / \mathrm{l})\end{array}$ & $\begin{array}{c}\alpha \text {-amylase activity } \\
(\mathrm{U} / \mathrm{ml})\end{array}$ \\
\hline Yeast extract (40) & $70.0 \pm 1.4$ & $3.2 \pm 0.1$ & $276.0 \pm 1.4$ \\
$\begin{array}{l}\text { Peptone (40) } \\
\text { Yeast extract (20) and }\end{array}$ & $70.7 \pm 0.5$ & $2.0 \pm 0.1$ & $280.0 \pm 0.6$ \\
$\begin{array}{l}\text { peptone (20) } \\
\text { Yeast extract (20) and } \\
\text { casamino acid (20) }\end{array}$ & $71.1 \pm 1.8$ & $1.5 \pm 0.1$ & $300.0 \pm 2.6$ \\
$\begin{array}{l}\text { Yeast extract (20) and } \\
\text { ammonium sulfate (20) }\end{array}$ & $40.0 \pm 1.7$ & $3.0 \pm 0.1$ & $280.0 \pm 3.3$ \\
$\begin{array}{l}\text { Yeast extract (20) and urea } \\
\text { (20) }\end{array}$ & $45.0 \pm 0.4$ & $18.2 \pm 0.7$ & $130.0 \pm 2.8$ \\
$\begin{array}{l}\text { Yeast extract (20) and beef } \\
\text { extract (20) }\end{array}$ & $67.0 \pm 1.4$ & $17.8 \pm 0.1$ & $140.0 \pm 0.9$ \\
$\begin{array}{l}\text { Yeast extract (20) and } \\
\text { Polypepton (20) }\end{array}$ & $66.0 \pm 0.3$ & $4.8 \pm 0.1$ & $270.0 \pm 1.3$ \\
\hline
\end{tabular}

Numbers in parenthesis denote the concentration $(\mathrm{g} / \mathrm{l})$ of the nitrogen source. 
Table 3

Effect of $\mathrm{pH}$ on cell growth and $\alpha$-amylase activity in batch culture of recombinant $P$. pastoris

\begin{tabular}{cccc}
\hline $\mathrm{pH}$ & Cell concentration $\left(\mathrm{OD}_{600}\right)$ & $\begin{array}{r}\text { Residual methanol } \\
\text { concentration }(\mathrm{g} / \mathrm{l})\end{array}$ & $\alpha$-amylase activity $(\mathrm{U} / \mathrm{ml})$ \\
\hline 3 & $38.2 \pm 1.4$ & $33.1 \pm 0.4$ & $180.2 \pm 2.8$ \\
4 & $52.2 \pm 0.4$ & $26.3 \pm 0.4$ & $250.3 \pm 1.7$ \\
5 & $69.3 \pm 1.7$ & $11.8 \pm 0.1$ & $385.6 \pm 0.8$ \\
6 & $72.2 \pm 1.1$ & $10.9 \pm 0.1$ & $415.3 \pm 1.0$ \\
7 & $68.0 \pm 1.3$ & $12.8 \pm 0.5$ & $390.2 \pm 0.4$ \\
8 & $55.1 \pm 1.2$ & $17.2 \pm 0.3$ & $350.2 \pm 1.5$ \\
9 & $30.3 \pm 2.0$ & $30.8 \pm 0.1$ & $200.4 \pm 0.9$ \\
\hline
\end{tabular}

Induction medium containing $50 \mathrm{~g} / \mathrm{l}$ of methanol was used. 
Table 4

Summary of $\alpha$-amylase production in the culture of recombinant $P$. pastoris

\begin{tabular}{lcccc}
\hline \multicolumn{1}{c}{ Culture method } & \multicolumn{2}{c}{ Batch culture } & \multicolumn{2}{c}{ Fed-batch culture } \\
\hline Nitrogen source feeding & $\mathrm{No}^{\mathrm{a}}$ & $\mathrm{No}^{\mathrm{b}}$ & $\mathrm{No}^{\mathrm{c}}$ & Yes $^{\mathrm{d}}$ \\
$\begin{array}{c}\text { Maximum cell concentration } \\
\left(\mathrm{OD}_{600}\right)\end{array}$ & $72.2 \pm 1.1$ & $95.1 \pm 0.6$ & $152.0 \pm 1.3$ & $179.1 \pm 1.3$ \\
$\begin{array}{c}\text { Maximum } \alpha \text {-amylase activity } \\
(\mathrm{kU} / \mathrm{ml})\end{array}$ & $0.42 \pm 0.01$ & $0.72 \pm 0.01$ & $1.14 \pm 0.04$ & $2.40 \pm 0.05$ \\
$\begin{array}{r}\text { Specific } \alpha \text {-amylase activity } \\
\left(\mathrm{kU} / \mathrm{l} / \mathrm{OD}_{600}\right)\end{array}$ & $5.8 \pm 0.1$ & $7.6 \pm 0.1$ & $7.5 \pm 0.1$ & $13.4 \pm 0.1$ \\
$\begin{array}{c}\text { Maximum enzyme production } \\
\text { rate }\end{array}$ & $5.8 \pm 0.1$ & $10.0 \pm 0.1$ & $7.9 \pm 0.5$ & $14.3 \pm 0.2$ \\
\hline
\end{tabular}

${ }^{a}$ Data cited from Table 3. Initial carbon source concentration was $50 \mathrm{~g} / \mathrm{l}$.

${ }^{\mathrm{b}}$ Data cited from Fig. 1. Carbon source was added at the culture time of 1 and $4 \mathrm{~d}$.

${ }^{\mathrm{c}}$ Data cited from Fig. 2 (mixture ratio of methanol to glycerol, 1:0.5).

${ }^{d}$ Data cited from Fig. 3 (mixture ratio of methanol to glycerol, 1:0.5). Nitrogen source was added at the culture time of 3 and $5 \mathrm{~d}$.

${ }^{\mathrm{e}}$ Maximum enzyme activity was divided by culture time. 


\section{Legends of Figures}

Fig. 1. Time course of concentrations of dissolved oxygen (a) and residual methanol (b), $\mathrm{OD}_{660}$ (c), and $\alpha$-amylase activity (d) in fed-batch culture of P. pastoris G2 in the jar fermentor. $20 \mathrm{~g} / \mathrm{l}$ of methanol was added at the culture time of 1 and $4 \mathrm{~d}$.

Fig. 2. Fed-batch culture of $P$. pastoris G2 in an induction medium. Stock solution of methanol and glycerol as a carbon source was fed at the feed rate of $13.6 \mathrm{ml} / \mathrm{h}$. The concentrations of stock solutions were 221 g/l (closed circles), 294 g/l (open circles), and 441 g/l (open triangles), and their mixing ratios of methanol and glycerol were 1:0.5, 1:1, and 1:2, respectively. (a) Time course of methanol concentration. (b) Time course of cell growth. (c) Time course of $\alpha$-amylase activity.

Fig. 3. Fed-batch culture of $P$. pastoris G2 in an induction medium with the addition of nitrogen source (closed circles) and without (open circles). Stock solution (221 g/l) of methanol and glycerol (1:0.5) as a carbon source was fed at the feed rate of $27.3 \mathrm{ml} / \mathrm{h}$. Forty grams per liter of nitrogen source containing 20 g/l yeast extract and 20 g/l peptone was added at the culture time of $3 \mathrm{~d}$ and $5 \mathrm{~d}$. (a) Time course of ammonia nitrogen concentration. (b) Time course of methanol concentration. (c) Time course of cell growth. (c) Time course of $\alpha$-amylase activity. 

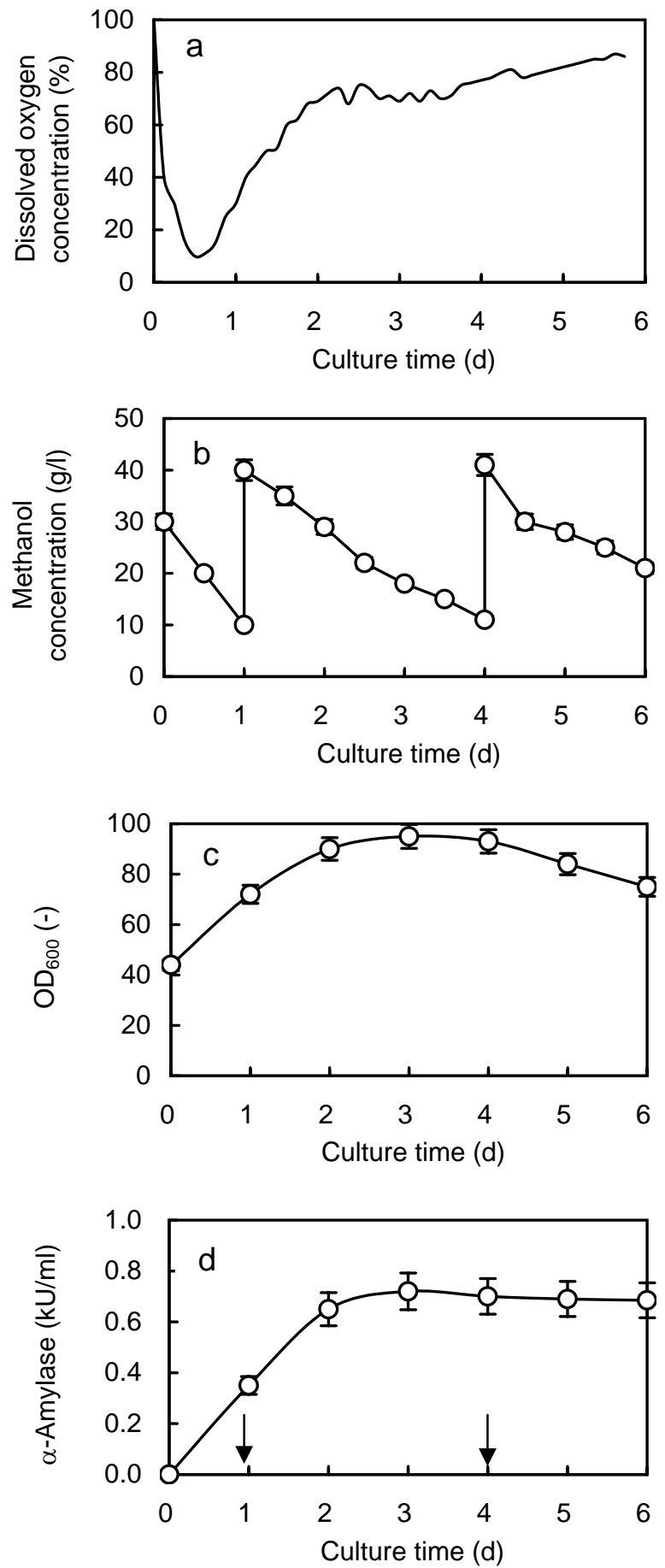

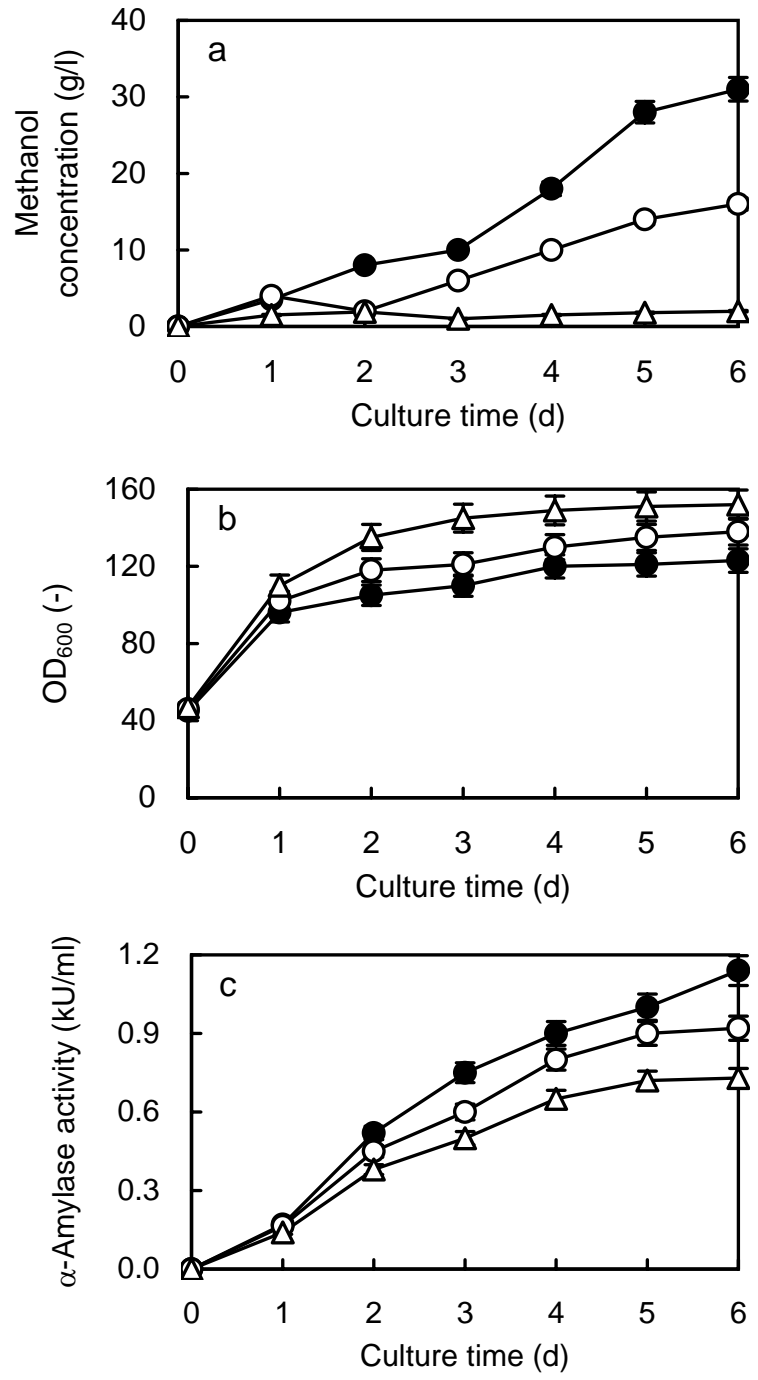

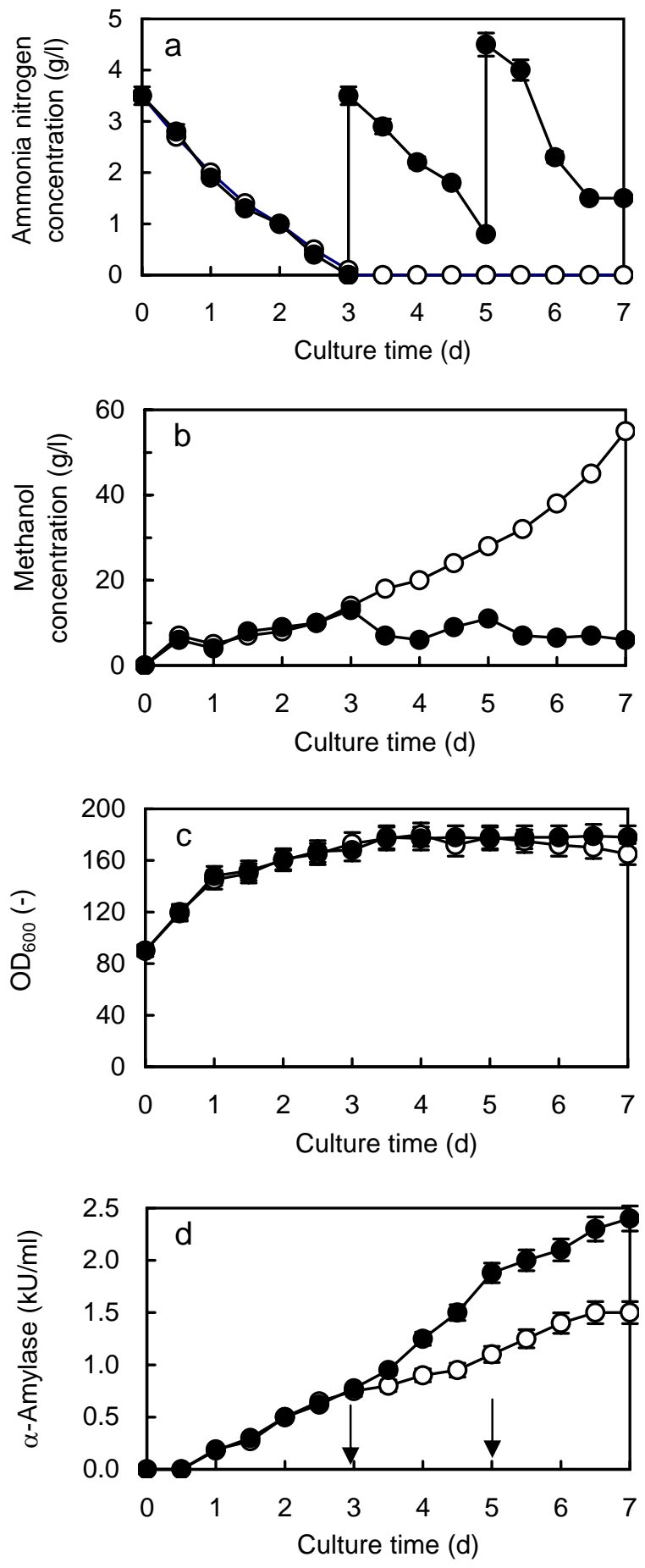